\title{
DEVELOPMEN'T OF EMBRYO SAC AND EMBRYO IN EUPHORBIA PRESLII AND E. SPLENDENS
}

WANDA WENIGER

(WITH PLATES XIV-XVI)

\section{Introduction}

LINNAEUS had considered the cyathium of Euphorbia to be a single flower, its involucre a perianth, and the staminate flowers stamens. The inaccuracy of these assumptions was demonstrated by BROWN (2), who substituted for them the conceptions still held, namely, that the cyathium consists of an involucre containing a single pistillate flower and many staminate flowers.

The earliest monograph of the Euphorbiaceae was that of BAIllon (I), in 1858 . He found that a character common to all species of the family is the uniovulate or biovulate locule. The anatropous or orthotropous ovule becomes a seed with 3 seed coats, the outer one of which usually disintegrates. The embryo is surrounded by an oily endosperm and has a rudimentary root cap. Baillon's figures, reproduced by Strasburger (20), show the structure of the nucellus and embryo of E. Lathyrus. The name "obturateur" was applied by BAILLON to the mass of cells which grows from the placenta, pushing into the micropyle, and which is thought to determine the direction of growth of, and to nourish, the pollen tube. The nucellus grows out into a beak before the time of fertilization and the cells of the obturator grow close to the nucellus.

The obturator was called by Mirbel (9) a "chapeau de tissu conducteur," by PAYER (15) a "capuchon," and by CAPUs (3), who studied E. Myrsinites in particular, a "coussinet micropylaire." Poissox (I6) describes the integuments and obturator of $E$. Lathyrus and E. Peplis. PAx's account (14) of the structure of the ovule agrees with that of BAILLON. According to him, however, caruncula and obturator are one and the same structure.

Miss Lyov (8) gives a full account of the life history of $E$. corollata. There are 3 carpels in each pistillate flower, forming a triBotanical Gazette, vol. 63] 
locular ovary with a single suspended anatropous ovule in each locule. The inner integument appears first, but it remains small, while the outer integument grows beyond it. The megaspore mother cell is subepidermal in origin, but the cells of the nucellus, and possibly those of the epidermis near the upper end of the embryo sac, divide with great rapidity, producing a long, slender neck, and leaving the embryo sac deeply imbedded. The embryo sac develops in the usual way from the lowest of a row of 4 axial megaspores. The synergids are extremely long and the egg is situated between them. The pollen tube passes between the synergids, and the fusion of the male nucleus with the egg nucleus was observed. The fusion of the polar nuclei takes place near the egg. The antipodal cells are ephemeral and were seen by Miss Lyon but once. The neck of the nucellus and the "glandular hairs," as the cells of the obturator are called, disintegrate after the entrance of the pollen tube, and the outer integument closes the mouth of the micropyle.

Hegelmaier (6) reports habitual polyembryony in E. dulcis. From 2 to 9 embryos appear at the micropylar end of the sac. One embryo, which comes from the egg and may be distinguished from the others by the presence of a suspensor, develops into the single embryo of the seed. Some of the supernumerary embryos come from the nucellus. Two of them often reach the cotyledon stage, with tissue systems differentiated; the other embryos appear as irregular masses. Since the cyathium of this species has a very small neck, Hegelmaier thinks it improbable that the flowers are insect pollinated. Wind pollination is also improbable, because of the regularity with which seeds are formed in the locules. In a later paper HEgelmaier (7) admits that, although fertilization in $E$. dulcis was not observed and although its possibility seems lessened by the sterility of a large proportion of the pollen grains, he cannot prove that it does not occur. Fertilization is not necessary for the production of the embryos from nucellar cells. There is a possibility that apogamy and also parthenogenesis occur.

ROEPER (I7) reports observing 2 embryos in the seed of E. platyphylla. According to De Candolle (5), 2 embryos are also formed in E. helioscopia. SchWeiger (I9) describes the obturator, nucellus, 
and caruncula of many species of Euphorbia. The outer integument always develops before the inner. The obturator of E. Myrsinites begins as a small outgrowth from the placenta when the outer integument has grown almost half-way to the tip of the nucellus. The cells of the obturator increase rapidly, the outer ones becoming long and hairlike. At the time of fertilization, the obturator is mature and has the shape of a bell which fits over the micropyle. The long cells of this structure completely fill the space between the nucellus and the inner and outer integuments, but never grow into the nucellar tissue. The obturator gradually disintegrates as the embryo enlarges, until at the maturity of the seed it is represented only by a small swelling on the placenta. The form and size of the obturator differ in different species. The nucellus has a long, slender tip which is surrounded by the cells of the obturator. The caruncula is formed from the outer integument, after the embryo has developed. A row of cells differentiates it from the seed proper. This structure resembles a cap and aids in loosening the seed from the placenta at the time of dispersal. Schmidt (I8) finds more than one megaspore mother cell in E. palustris. These are situated deep in the cells of the nucellus. His account of the development of the flower agrees with that of Miss Lyon (8).

Modilewski (II) describes an unusual development of the embryo sac in E. procera. The first 4 nuclei of the embryo sac are arranged in the form of a cross. Two divisions result in the formation of 4 tetrads of nuclei. One nucleus from each group migrates to the center of the sac, where the 4 unite. The mature embryo sac contains an egg apparatus, 3 antipodal cells, and 2 groups of 3 nuclei each, lying on opposite sides of the sac. In fertilization, one male nucleus fuses with the egg nucleus, and the other male nucleus fuses with the quadrivalent fusion nucleus in the center. The synergids, antipodals, and nuclear groups at the sides of the sac disintegrate. No case of polyembryony was observed. Later, Modilewski (I2) described the events preceding embryo sac development in E. procera. An archesporial row of 3 or 4 cells was found, each ultimately containing 4 nuclei. Only one of the 4-nucleate cells develops into an embryo sac. Often one or more 
of the other cells of the row adheres to the developing sac for some time before it disintegrates.

According to Modilewski, the embryo sacs of E. Lathyrus, E. salicifolia, E. globosa, E. meloformis, E. Cyparissias, E. coralloides, E. variegata, E. helioscopia, E. Gerardiana, E. Ipecacuanhae, and E. heterophylla develop normally. Dessiatoff (4) describes the formation of 16 nuclei in E.virgata, in a manner similar to that described by Modilewski for E. procera (II). In a still later study, ModiLEWSKI (I3) finds I6 nuclei in the embryo sac of E. palustris. The development proceeds exactly as in E. procera. On the other hand, the embryo sacs of E. virgata and E. lucida develop in the ordinary way. Modilewski, whose material for the study of $E$. virgata was collected from various localities, disagrees with Dessiatoff's notion of the structure of the embryo sac in this species (4). He thinks that the nuclei in Dessiatoff's figures of the embryo sac resemble endosperm nuclei more than they do those of ordinary embryo sacs. He finds, also, that at the 2- and 4-nucleate stages the megaspore enlarges so rapidly that its wall becomes indistinct, and that the cells of the nucellus, which have been pushed aside in the growth of the spore, might easily be taken for nuclei of the developing gametophyte. Dessiatoff, according to MoDILEWSKI, mistook either endosperm or nucellar nuclei for nuclei of the mature embryo sac. If this is not the explanation of his results, Modilewski thinks Dessiatoff was mistaken in the determination of the species studied. MöвIUs (Io) has recently figured the relation of the integuments and obturator to the nucellus in E. macrorrhiza.

$E$. procera and E. palustris, on the present evidence, seem to be the only species of Euphorbia studied which deviate from the usual history of the embryo sac. In these species, Modilewski found that since the endosperm nuclei are very large and usually contain 2 or 3 nucleoles, there is no danger of their being confused with the nuclei of the mature embryo sac.

\section{Material and methods}

Flowers and seeds of Euphorbia Preslii were collected in different stages of development during July and August 1915, along 
railroad tracks in Madison, Wisconsin. They were fixed in Flemming's strong, medium, and weak fixatives, the first named giving the best results. Young buds, flowers, and seeds of E. splendens were fixed in various fixing solutions, including Flemming's, Carnoy's, and Juel's, and acetic alcohol fixatives. The best results in this case were obtained with the latter, the Flemming solutions failing to penetrate soon enough, due to the great amount of latex in all portions of the plants. The material was obtained during March and April i9ı6, from plants grown in the greenhouse. Sections were cut 5 or $6 \mu$ in thickness. Some sections of embryos Io $\mu$ thick were made. Flemming's triple stain was used with good results.

\section{Observations}

\section{Euphorbia PresliI}

\section{Cyathium}

The first evidence of the formation of the cyathium in this species is the appearance of a papilla (fig. I, $p$ ) between 2 bracts (b) at the end of a peduncle. At the base of this papilla, staminate flowers (fig. 2, $s^{\mathrm{r}}$ ) and the bracts of the involucre (in) soon appear. The outer bracts $(b)$ continue to grow up about the developing cyathium. Ovules (fig. 3,o) next arise as small swellings on the central papilla $(p)$. The carpels $(c)$ of the pistillate flower appear at the base of the papilla and gradually grow up about it, forming a short style and 3 deeply 2 -lobed stigmas (fig. $4, s g$ ). The involucre now grows up about the staminate and pistillate flowers. The staminate flowers never extend above the neck of the involucre; in the early stages of the history of the pistillate flower only the stigmas project beyond the neck of the involucre. The pistillate flower consists of a single pistil, whose trilocular ovary terminates a stalklike structure which is jointed below to the pedicel (fig. 32). Soon after fertilization the stalk of the pistillate flower elongates, causing the pistil to project from the cyathium and nearly to close the opening of the involucre. When a stamen is nearly mature a depression appears, marking the point of juncture of the pedicel and the filament. Secondary staminate flowers arise as branches from the older ones (fig. $3, s^{2}$ ). This description of the develop- 
ment of the cyathium agrees with that given by Miss Lyon (8) for E. corollata.

\section{Embryo sac}

A single ovule (fig. 4, o), which soon becomes anatropous, is formed in each locule of the ovary. Before the integuments begin to appear, the megaspore mother cell can be distinguished by the size of its nucleus (figs. 5, II). It is subepidermal in origin and larger than the surrounding cells of the nucellus. After increasing considerably in size (fig. 1 2), 2 divisions occur which result in the formation of a typical row of 4 megaspores (fig. I3), of which the innermost is the largest and the one destined to develop into the embryo sac.

The inner integument begins to develop first (fig. $7, i i$ ), but the outer $(o i)$, which appears a little later, grows the more rapidly. It has been stated by Poisson (I6), working on E. Lathyrus and E. Peplis, and by Schweiger (20), investigating many species of Euphorbia, that the outer integument develops before the inner. It would be easy to arrive at a similar conclusion in the case of $E$. Preslii, since one rarely obtains a preparation showing the stage at which the inner integument is appearing at the base of the nucellus before any trace of the outer is to be seen, and since the outer integument grows so rapidly that it very early extends beyond the inner. In all probability, closer study of this species would show that in these also the inner integument begins its development first, as is the case in E. corollata, E. Preslii, and E. splendens.

At the time of the first nuclear division in the functional megaspore, the outer integument reaches about half-way to the tip of the nucellus; the inner integument is still extremely small (fig. 8). As the inner integument begins to grow more rapidly, the obturator first appears as a small swelling on the placenta (fig. 8, ob). Its cells increase in number (fig. Io, $o b$ ), the outer ones becoming long and slender and giving to the structure a very irregular outline. The nucellus grows out into a long beak (fig. Io, $n$ ) which extends beyond the integuments. At this time, the developing embryo sac has reached the 8-nucleate stage, and the obturator completely fills the space between the beaklike prolongation of the nucellus, 
the placenta, and the ovary wall. The outer integument always extends considerably beyond the inner, even at the maturity of the embryo sac (fig. Io). The sac becomes deeply imbedded in the cells of the nucellus (figs. 9, ro). It is very long, and averages about 5 or $6 \mu$ in thickness.

The functional megaspore grows considerably (fig. 14) before the first division of its nucleus. The other 3 megaspores disintegrate, but are visible at least as late as the 4-nucleate stage of the embryo sac as small, dark-staining cells at the micropylar end of the sac (fig. I 7). The 2 nuclei resulting from the first division are usually to be found near the respective ends of the sac (fig. I6). In one case observed (fig. I7), however, one nucleus of each pair had moved nearer the center of the sac. That the latter case is exceptional is indicated by the fact that the 8 nuclei formed by the third division lie in 2 groups of 4 each at the respective ends of the sac. Cell division now occurs in the typical way (fig. 15). The synergids are oval in shape and each has a characteristic vacuole below the nucleus. The egg extends farther toward the center of the sac than the synergids. The 3 antipodals are well defined, angular cells, each with a conspicuous vacuole. After cell division is completed, the polar nuclei remain for a time in what seem to be their original positions near the respective ends of the sac (fig. I8). In one case they were found to have moved nearer the center of the sac (fig. I9), but no case was observed in which they had come in contact with each other previous to fertilization. Modilewski (13) found no evidence of a fusion of the polar nuclei in $E$. virgata, which has a typical embryo sac of 8 nuclei. HegeLMAIER (6) found no fusion of either male or female nuclei, or of polar nuclei, in E. dulcis. I found no case showing actual fertilization. Fig. I9 shows the antipodal cells and the synergids apparently disintegrating, but the polar nuclei have not yet fused, and the egg nucleus shows no evidence of fusion with a male nucleus. This history differs from that observed by Miss Lyon in E. corollata, where the antipodal nuclei are ephemeral and were observed but once, and where the polar nuclei fuse soon after their formation.

It is difficult to trace the course of the pollen tubes, should they be present, because of the long cells of the obturator. There seems 
to be little possibility for self-pollination, for the neck of the cyathium is very small and the staminate flowers do not extend above the surface of the cyathium. When the embryo sac is mature, the staminate flowers are still rudimentary. Insect pollination is improbable because of the smallness of the cyathium and the smallness of the opening. Seeds are formed with marked regularity, which would hardly be the case if wind pollination occurred. Hegelmaier $(6,7)$ found the same conditions with regard to pollination in E. dulcis.

\section{Embryo}

The fertilized egg divides in a plane parallel with the long axis of the sac (fig. 20). The second division occurs at right angles to the plane of the first (fig. 21). Further divisions result in the formation of a globular mass of cells (figs. 22, 23, 24). In all cases observed, the embryo formed no suspensor. The beak of the nucellus and the obturator gradually disintegrate as the embryo is formed, and the inner and outer integuments grow so as nearly to fill the large opening originally constituting the micropyle, but still leaving a small opening (fig. 25).

As early as the 2-celled stage of the embryo, endosperm nuclei appear at either side of the embryo. In the case represented in fig. 20, one endosperm nucleus (en) lies between the embryo and the micropylar end of the sac. The endosperm nuclei increase rapidly in number and are distributed quite uniformly throughout the peripheral region of the sac (fig. 24). Cell division does not occur in the endosperm until the embryo has come to consist of several hundred cells. The endosperm gradually fills the space originally occupied by the nucellar tissue (fig. $25, n$ ).

The embryo changes as it grows from a globular (fig. 26) to an elongated form (figs. 28, 29). Fig. 30 shows the earliest stage at which cotyledons were observed. A well developed root cap is present in the mature embryo (figs. 27, 3I, rc). When mature, the embryo (figs. 27, 3I) is straight and its length nearly equals that of the seed, the root cap $(r c)$ being pressed closely against the micropyle. Surrounding the embryo, except at the tip of the root cap, is the endosperm (fig. 27, end), whose cells contain a large amount of reserve food material in the form of starch, fat, and aleurone grains. 


\section{EUPHORBIA SPLENDENS}

\section{Embryo sac}

The flowers of this species develop just as do those of E. Preslii, and there is also a similarity in the general structure of the obturator and the ovule. As in E. Preslii, the megaspore mother cell may be distinguished before the integuments have begun to develop (fig. 33). The mother cell is easily recognizable by its size, being several times as large as the surrounding cells of the nucellus, and by the fact that it contains a very large nucleus. It is situated 3 layers beneath the epidermis, and although in numerous cases I have found it only in this position, it is probable that in this species also it originates as a subepidermal cell and that the cells of the nucellus above it divide so that it comes to lie more deeply in the nucellus. After the mother cell (fig. 34) grows and elongates, and its nucleus also grows considerably, the latter prepares for division. At the time of the synaptic stage (figs. 35, 36), the nucleus has moved to the micropylar end of the cell. One unusually favorable preparation showed a late anaphase of the heterotypic division (fig. 37). The spindle in this figure occupies a central position and its long axis lies in the plane of the long axis of the nucellus. There are I 2 small, nearly spherical daughter chromosomes in each of the 2 groups on the spindle.

Although the formation of the row of 4 megaspores was not observed, it is certain that 4 are formed, for when the functional megaspore has increased in size (fig. 38), 3 dark-staining masses can be distinguished at its micropylar end. This stage agrees with the corresponding one in E. Preslii, in which it is plainly the innermost of the 4 megaspores that develops into the embryo sac. This megaspore (fig. 38), even at the division of its nucleus, is not as large as the megaspore mother cell. In one case (fig. 39) 2 developing megaspores were found lying parallel to each other with their long axes parallel to the long axis of the nucellus. Each has a dark-staining mass of apparently 3 disintegrating cells at the micropylar end, but the number of these cannot be distinguished with certainty. This occurrence of 2 functional megaspores is doubtless very unusual, for it was observed in but one ovule. 
The developing embryo sac becomes deeply imbedded in the nucellar tissue. After some growth of the functional megaspore, its nucleus divides (fig. 40) and one daughter nucleus moves to each end of the cell. At this stage further growth takes place, and while the first and second divisions of the nucleus (figs. 40, 4I) are taking place, a large central vacuole is formed which persists for some time. An 8-nucleate stage was not found. In two cases 4 nuclei were found at the micropylar end (fig. 42), but only 3 at the antipodal end of the sac. In most cases in which the egg apparatus had been differentiated, no nuclei were to be found at the antipodal end of the embryo sac, indicating that the antipodal nuclei (and cells, if formed) must be ephemeral, unlike the antipodal cells of E. Preslii. Fig. 43 shows a sac with the egg apparatus fully formed and the polar nuclei apparently about to fuse near the egg, while the antipodal end of the sac shows 2 daughter nuclei of a recent division, with a cell plate between them. It is possible that after the second nuclear division in the developing megaspore, one of the two nuclei at the antipodal end divides some time before the other. One of the daughter nuclei of this (the third) division might then move to the micropylar end and function as a polar nucleus, its sister nucleus disintegrating before the remaining nucleus in the antipodal end (a daughter nucleus of the second division) finally divides. This explanation would also fit in with the condition found in the sac shown in fig. 42 , which had only 3 nuclei at the antipodal end.

Fig. 44 shows another peculiar embryo sac in which there are plainly 8 nuclei at the antipodal end of the sac, at least 3 of which are surrounded by cell membranes. In this case, it is conceivable that each of the 4 nuclei at the antipodal end of the sac has divided and that none has as yet disintegrated. In all but these cases, the antipodal nuclei (or antipodal cells) had disintegrated. The egg apparatus seems to be quite typical (figs. 43, 45). At first the nucleus of the egg occupies the center of the cell, but later, as the egg grows, the nucleus moves to the side of the cell farthest from the micropyle. The egg is spherical, and its nucleus is not, in general, larger then the nuclei of the synergids. In the sac shown in fig. 45 one of the polar nuclei lies close to the egg, while the other seems 
to be moving along the side of the sac toward the egg. The polar nuclei are at first not as large as the other nuclei of the sac, but before their fusion (fig. 46) they increase in size, each becoming larger than the egg nucleus. Fusion takes place below the egg in a plane either at right angles to (fig. 46) or parallel with (fig. 47) the long axis of the sac. The 2 nucleoles persist in the fusion nucleus until fertilization takes place.

The embryo sac of E. splendens differs from that of E. Preslii chiefly in the history of the antipodal cells, which in the latter species persist for some time after their formation; another difference is that in E. Preslii the polar nuclei remain in their original positions until after cell division occurs.

If fertilization does not occur immediately after the fusion of the polar nuclei, the synergids disintegrate, leaving the egg and the fusion nucleus close together at the micropylar end of the sac. In 2 embryo sacs in which fertilization was observed, the synergids were disintegrating, but their nuclei were still recognizable as dark-staining masses. In the sac shown in fig. 48 , the pollen tube has destroyed one of the synergids and discharged one male nucleus, which may be seen in contact with the nucleus formed by the fusion of the polar nuclei. The latter nucleus still shows 2 nucleoles and is considerably larger than the egg nucleus. It has already moved a little way toward the antipodal end of the sac. The male nucleus also possesses 2 nucleoles and is crescent-shaped. The second male nucleus is a dark-staining mass still in the pollen tube and little more than its nucleole can be distinguished. It is about to pass down to the egg nucleus, the tip of the tube being within the cell membrane of the egg. Fig. 49 shows another pollen tube which has not yet discharged its male nuclei. It contains densely staining material which seems to be aggregated into several masses, but no nuclei are distinguishable. The polar nuclei in this case have not completely fused and the egg nucleus is in a resting stage. The pollen tube could not be traced back into the micropyle in either case, for only its tip seems to contain material that stains densely. With the triple stain, the contents of the tip of the tube always take up the safranin. Fertilization does not take place at the same time in the 3 ovules within the same pistil. A pollen 
tube may be seen in each of them, but in one case it may be discharging its nuclei, while in another case the endosperm nucleus may have undergone several divisions. Figs. 48 and 50 were drawn from 2 embryo sacs within the same ovary.

\section{Embryo}

The fertilized egg does not divide immediately after the fusion of the nuclei within it. Usually there are 5 or 6 nuclear divisions in the endosperm before division of the egg occurs. In the sac shown in fig. 50, there are 4 endosperm nuclei, the egg still being undivided. The first division of the egg (fig. $5 \mathrm{I}$ ) is at right angles to the long axis of the nucellus. The developing embryo forms a short suspensor which is several cells in diameter. The terminal cell divides by a longitudinal wall after the embryo is about 4 cells in length (fig. $5^{2}$ ). There seems to be nothing definite about the planes in which later walls are formed (figs. 53, 54), but a more or less globular mass of cells is formed at the end of the short suspensor (figs. 55, 56). In the embryo represented in fig. 56 the suspensor seems to be disintegrating. The mature embryo has a structure similar to that of $E$. Preslii, there being a well differentiated root cap and epicotyl.

\section{Summary}

I. The cyathium of both species studied begins as a papilla which arises between two bracts. The order of appearance of the parts of the cyathium is as follows: staminate flowers, involucre, ovules, carpels, and secondary staminate flowers which arise as branches of the first set.

2. The megaspore mother cell is subepidermal in origin in E. Preslii, and probably also in E. splendens.

3. An axial row of 4 megaspores is formed, the lowest of which develops into the embryo sac; the other 3 spores disintegrate.

4. The inner integument begins to develop before the outer, but the latter grows rapidly and soon overtops the inner.

5. The mature embryo sac is long and narrow, and is deeply imbedded in the tissue of the nucellus. In E. Preslii it has the 
structure usual in angiosperms. In E. splendens there are peculiarities in the history of the antipodal nuclei which require further study to make definite conclusions possible. It seems probable that each of the 4 antipodal nuclei may undergo a second division.

7. The obturator arises as an outgrowth of the placenta. It fills the space between the beaklike prolongation of the nucellus, the placenta, and the ovary wall. Its cells disintegrate after the embryo begins its development.

8. At about the time of the first division of the egg of E. Preslii, endosperm nuclei come to lie between it and the micropylar end of the embryo sac.

9. The embryo becomes a round mass of cells; this mass elongates and later 2 cotyledons and a well developed root cap are formed. The mature embryo is straight, and, except at the tip of the root cap, is surrounded by the endosperm. In E. Preslii no suspensor was observed; in E. splendens there is a short suspensor.

This paper is the result of work carried on at the University of Wisconsin under the supervision of Dr. C. E. Alles, for whose kind assistance I wish to express my sincere appreciation.

University of Chicago

\section{LITERATURE CITED}

I. BaIllon, E. H., Etude général du group des Euphorbiacées. Paris, 1858; rev. in Bull. Soc. Bot. France 5:776-780. 1859 .

2. Brown, R., Miscellaneous works. London. 1866 (vol. I, p. 28).

3. Capus, G., Anatomie du tissu conducteur. Ann. Sci. Nat. Bot. VI. 7:209291. 1878 .

4. Dessiatoff, N., Zur Entwicklung des Embryosacks von Euphorbia virgata. Ber. Deutsch. Bot. Gesells. 29:33-39. I9I I.

5. De Candolle, A. P., Organographie végétale. 3:71. 1827; cited by Hegelmaier (6).

6. Hegelmaier, F., Über einen neuen Fall von habitueller Polyembryonie. Ber. Deutsch. Bot. Gesells. 19:488-499. I9 I I.

7. — Zur Kenntnis der Polyembryonie von Euphorbia dulcis. Ber. Deutsch. Bot. Gesells. 21:6-19. 1913. 
8. Lyon, Florence, Contribution to the life history of Euphorbia corollata. Вот. GAZ. 25:418-426. I898.

9. Mirbel, C. F., Histoire naturelle générale et particulière des plantes. Paris. I800-I809; cited by Hegelmaier (6).

10. MöвıUs, M., Microscopisches Practicum für systematische Botanik. Berlin. I9I2 (pp. I07-IO9).

Ir. Modilewski, J., Zur Embryoentwicklung von Euphorbia procera. Ber. Deutsch. Bot. Gesells. 27:2 I-26. I909.

12. - Weitere Beiträge zur Embryoentwicklung einiger Euphorbiaceen. Ber. Deutsch. Bot. Gesells. 28:413-418. I910.

13. _- Die anomale Embryosackentwicklung bei Euphorbia palustris. Ber. Deutsch. Bot. Gesells. 29:430-436. I9I I.

14. Pax, F., Euphorbiaceae. ENGLeR und Prantl, Die natürlichen Pflanzenfamilien. 5: I-I I9. Leipzig. I 887.

15. Payer, J. B., Traité d'organogénie comparée de le fleur. Paris. 1857; cited by SchWEIGER (20).

16. Poisson, J., Du siège des matières colorées dans la graine. Bull. Soc. Bot France 25:47, 60. 1878 .

17. Roeper, J. A. C., Enumeratio Euphorbiarum. I824 (pl. I. fig. 67); cited by Hegelmaier (6).

18. Sснмidт, H., Über die Entwicklung der Blüten und Blütenstände von Euphorbia. Beih. Bot. Centralbl. 22:21-69. 1907.

19. Schweiger, J., Beiträge zur Kenntnis der Samenentwicklung der Euphorbiaceen. Flora 94:339-382. 1905.

20. Strasburger, Jost, Schenk, und Karsten, Lehrbuch der Botanik. Jena. I9Io (pp. 473-477).

\section{EXPLANATION OF PLATES XIV-XVI}

All drawings were made with an Abbé camera lucida at table level, and Leitz oculars and objectives. The following combinations were used: ocular 4 , objective 3 , tube length I70 mm. ( $\times 200)$, figs. I-IO, 24, 28-3I; ocular 4, objective 6 , tube length $\mathrm{I} 70 \mathrm{~mm}$. ( $\times 800)$, figs. I I, 23; ocular 4 , oil immersion I/I6, tube length I $70 \mathrm{~mm}$. ( $(2000)$, figs. I2, I3, 22, 33, 4I, 45-47; ocular 4 , oil immersion I/I6, tube length $212 \mathrm{~mm}$. ( $\times 2600)$, figs. I4-2I, 34-40; ocular I, objective 3 , tube length $\mathrm{I} 40 \mathrm{~mm}$. ( $\times$ IOO), figs. $25,27,32$; ocular 4 , oil immersion I/I6, tube length $\mathrm{I} 40 \mathrm{~mm}$. (X I700), figs. $42^{2-44}, 48-56$.

The following abbreviations are used: $b$, bract; $c$, carpel; cot, cotyledon; $e n$, endosperm nucleus; end, endosperm; $i$, integument; $i i$, inner integument; in, involucre; $n$, nucellus; $o$, ovule; $o b$, obturator; oi, outer integument; $p$, papilla; $r c$, root cap; $s^{\mathrm{I}}$, staminate flower; $s^{2}$, secondary staminate flower; sg, stigma.

In all figures the micropylar end is at the top of the drawing; figs. I8, I9, 2 I, $4^{2-5}$ are reconstructed from 2 or 3 sections each. 
PLATE XIV

Euphorbia Preslii.-Fig. I.-Appearance of a papilla which will develop into a cyathium.

Fig. 2.-Staminate flowers and involucre developing at base of papilla.

FIG. 3.-Ovules appearing at top of papilla, and carpels, staminate flowers, and involucre at base; at the left, a secondary staminate flower.

FIG. 4.-Longitudinal section of cyathium, showing 2 ovules within the ovary, and developing staminate flowers at base of pistillate flower; integuments have not yet appeared.

FIG. 5.-Nucellus, containing megaspore mother cell, but with no integuments as yet.

Fig. 6.-Inner integument just appearing at base of nucellus.

Fig. 7.-Inner and outer integuments at base of nucellus; embryo sac is developing.

Fig. 8.-Obturator appearing on placenta, and outer integument overtopping inner.

Fig. 9.-Obturator pushing up to nucellus.

FIG. I0.-Mature embryo sac deeply imbedded in tissue of nucellus, which has developed a beak; the long cells of obturator have filled space between nucellus and placenta.

FIG. I I.-Nucellus, showing megaspore mother cell.

FIG. I 2.-Megaspore mother cell before division.

FIG. I3.-Axial row of 4 megaspores.

FIG. I4.-Functional megaspore, now deeply imbedded in nucellar tissue.

FIG. I5 - Binucleate embryo sac.

FIG. I6.-Four-nucleate embryo sac.

Fic. I7.-Four-nucleate embryo sac, with 2 of nuclei near center of sac; an unusual condition.

Fig. I8.--Mature embryo sac.

FIG. 19.- Polar nuclei have moved nearer center of sac; synergids and antipodal cells seem to have disintegrated.

Fig. 20.-Two-celled embryo, with endosperm nuclei; one of latter between embryo and micropylar end of sac.

FIG. 21.-Four-celled embryo; several endosperm nuclei between embryo and micropylar end of sac.

FIG. 22.-Embryo a globular mass of cells.

FIG. 23.-Still later stage in development of embryo.

\section{PLATE XV}

E. Preslii.-FIg. 24.--Longitudinal section of seed, with embryo at micropylar end of embryo sac, and endosperm nuclei distributed in peripheral region of sac.

FIG. 25.-Elongated embryo imbedded in endosperm.

Figs. 26, 28, 29, 30.-Elongation of embryo and appearance of cotyledons. 

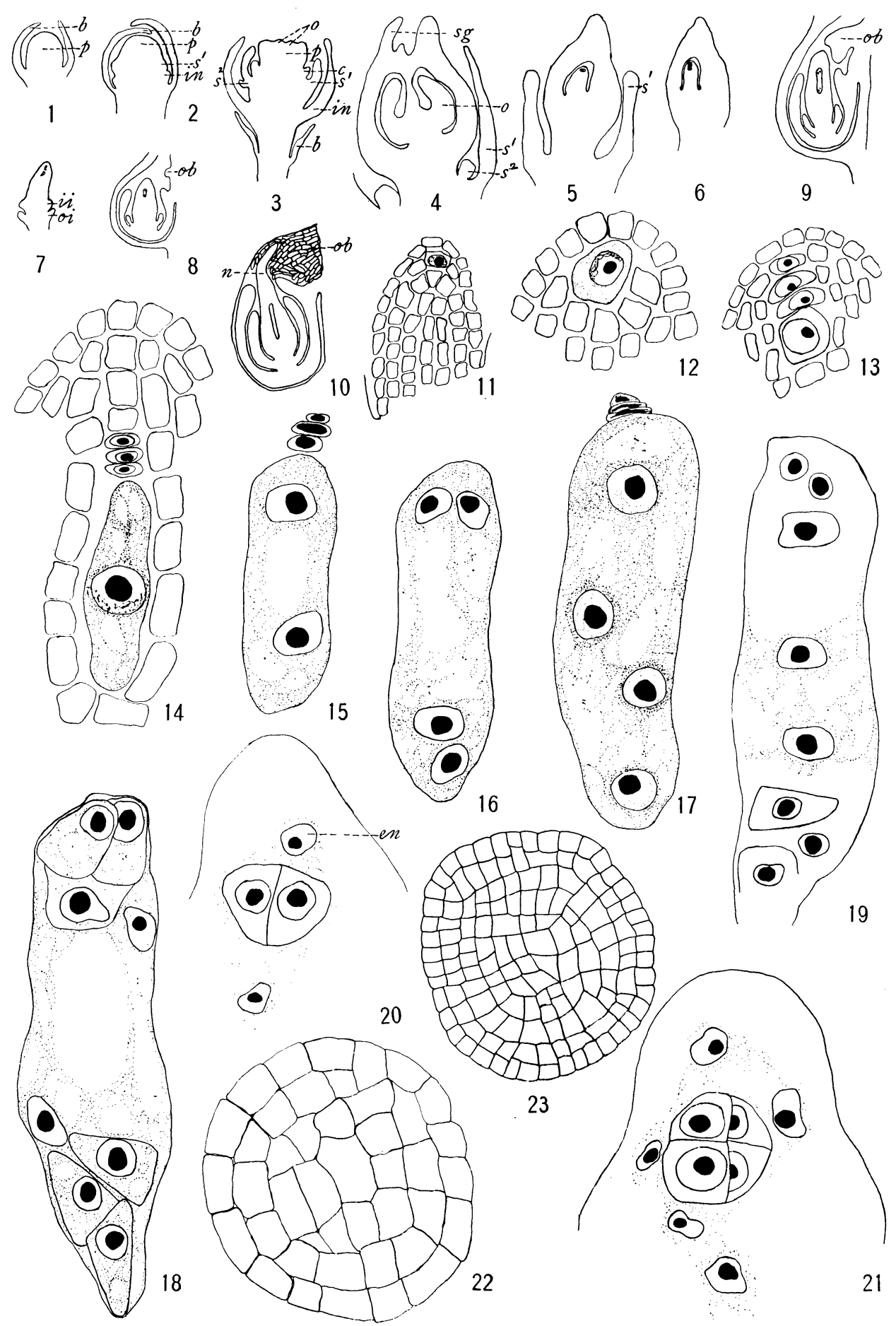

WENIGER on EUPHORBIA 

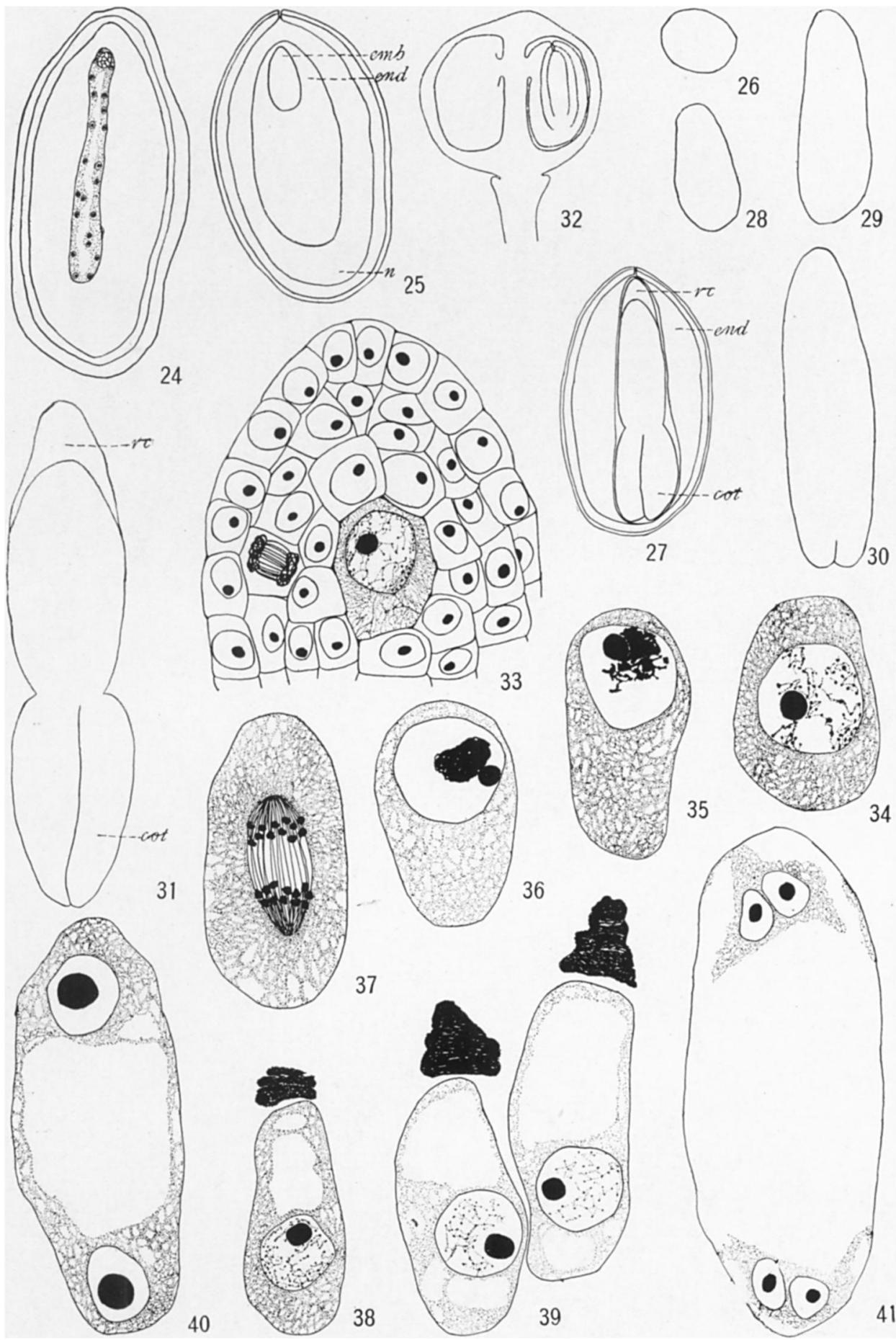

WENIGER on EUPHORBIA 


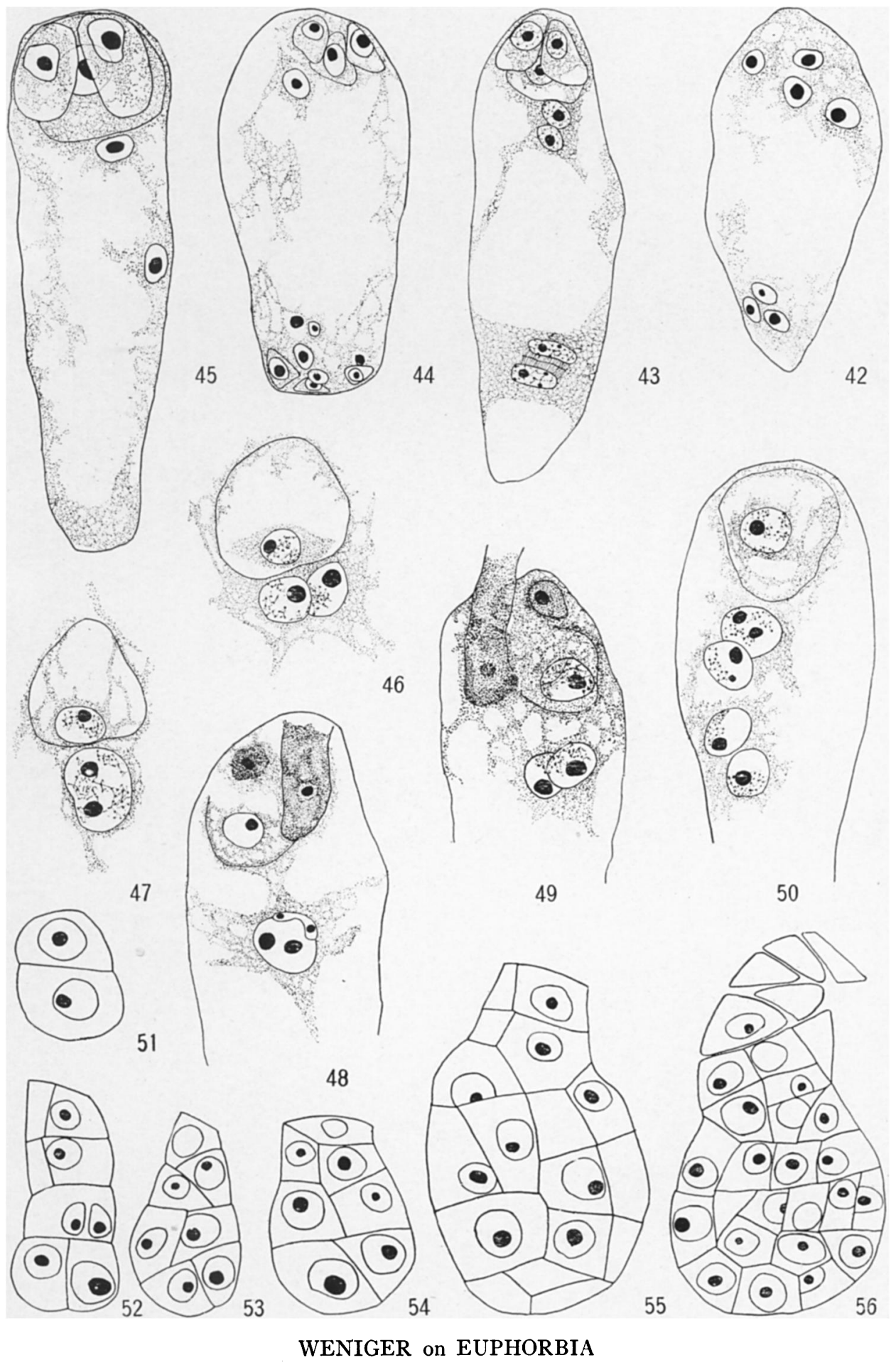


FIG. 27.-Mature seed in longitudinal section.

FIG. 31.-Mature embryo.

FIG. 32.-Pistillate flower, with ovary jointed to pedicel.

E. splendens.-FIG. 33.-Nucellus with megaspore mother cell 2 layers below epidermis.

FIG. 34.-Megaspore mother cell with resting nucleus.

FIGS. 35, 36.-Synapsis in megaspore mother cell.

FIG. 37.-Anaphase of heterotypic division in megaspore mother cell.

Fig. 38.-Lowest of the 4 megaspores, which is to develop into embryo sac; other 3 megaspores have disintegrated.

Fig. 39.-Two functional megaspores side by side, each accompanied by what appear to be 3 disintegrating megaspores.

FIG. 40.-Binucleate embryo sac.

FIG. 41.-Four-nucleate embryo sac.

PLATE XVI

Fig. 42.-Embryo sac with 4 nuclei at micropylar end, and only 3 at antipodal end.

FIG. 43.-Embryo sac showing egg apparatus fully formed; 2 polar nuclei about to fuse near micropylar end; 2 daughter nuclei with cell plate near antipodal end.

FIG . 44- - Embryo sac with egg apparatus and I polar nucleus at micropylar end; 8 nuclei at antipodal end, 3 of which are inclosed by cell membranes.

FIG. 45.-Polar nucleus from antipodal end approaching other polar nucleus which lies close to egg apparatus.

Fig. 46.-Polar nuclei about to fuse near egg.

Fig. 47.-Polar nuclei fused, but 2 nucleoles still persisting; egg nucleus at one end of cell.

FIg. 48.-Fertilization: one male nucleus in contact with nucleus formed by fusion of polar nuclei; other male nucleus is still in pollen tube.

FIG. 49.-Pollen tube within embryo sac; no evidence of fertilization, and male nuclei not distinguishable within pollen tube; polar nuclei about to fuse.

Fig. 50.-Fertilized egg still undivided; 2 nuclear divisions have occurred in endosperm.

FIG. 51.-First division of egg.

FIG. 52.-Young embryo with terminal cell divided by longitudinal wall.

FIGS. 53, 54.-Later stage in embryo development.

Fig. 55.-Embryo consists of rounded mass of cells at end of a short suspensor.

FIG. 56.-Embryo has increased in size, and suspensor is beginning to disintegrate. 